\title{
A BEHAVIOURAL APPROACH TO RANKING ACADEMIC DEPARTMENTS BY PRESTIGE: THE CASE OF SOCIOLOGY IN ENGLISH-SPEAKING CANADA ${ }^{1}$
}

\author{
by \\ John Goyder \\ (Department of Sociology, University of Waterloo; \\ jgoyder@uwaterloo.ca)
}

\begin{abstract}
Résumé - Une approche comportementale du classement des départements universitaires par prestige - Le cas de la sociologie au Canada anglophone : Du fait du déclin récent de la participation à des enquêtes, le prestige académique est devenu plus difficile à mesurer. Même si le biais du taux important de non-réponse des professeurs pouvait être ignoré, la crédibilité de telles enquêtes pourrait être critiquée. En sociologie, l'indice de citation est moins utile à titre d'alternative que dans des discipline plus consensuelles et plus basées sur les publications comme l'économie. Les sociologues publient dans une grande variété de formats et leurs productions les plus importantes sont souvent des livres. On rend compte ici, d'une approche comportementale de la mesure du prestige académique sur la base du croisement entre les établissement d'origine où les membres du personnel du département ont passé leur thèses de doctorat (un descripteur large mais peu précis) et le départements de sociologie où ils ont été engagés (un descripteur plus étroit mais plus précis). Cette étude concerne les universités anglophones du Canada. 'Prestige académique, Enquêtes de prestige, Départements de sociologie, Origines doctorales, Embauches, Canada.
\end{abstract}

\begin{abstract}
Academic prestige has, due to the $21^{\text {st }}$ century culture of declining survey cooperation, become harder to measure accurately using reputational surveys. Even if the high nonresponse on a survey of professors were ignorable in terms of bias, the credibility of such a survey would be challenged. Within sociology, citation index counts are not as useful an alternative as in more consensual and article-based disciplines such as economics. Sociologists publish in an immense variety of outlets, with much of the most important work appearing in books. Reported herein is a behavioural approach to academic prestige, based on each department's profile of doctoral origins of staff members (termed a broad by fuzzy approach) and on dominance within the hiring exchange matrix (giving a narrow but clearer reading). The case study is departments of sociology within English-speaking Canada. Academic Prestige, Reputational Surveys, Departments of Sociology, Doctoral Origins, Hirings, Canada.
\end{abstract}

\footnotetext{
'Adapted from a paper presented at the $43^{\text {rd }}$ Annual Meeting of the Canadian Sociological Association, Vancouver B.C., June 2008. Research assistants were Corinne Carter, Jaime Robinson, Michelle Seager and Emily Pomeroy. Funding came in part from the University of Waterloo Work Placement Program for co-op students. Thanks to M.E. Thompson, Statistics and Actuarial Science, UW, for assistance with the Bonacich measure. I benefitted from comments and reactions by Carl Cuneo, Neil McLaughlin, Bob Brym, Reza Nakhaie, and Jim Conway.
} 
Prestige is funny stuff. It is inertial, slow to accumulate as demonstrated in research on the prestige of "old money" (Warner and Lunt, 1942), but equally slow to dissipate due to the "Matthew Effect" from Merton (1968). It is sticky, in the sense that prestige rubs off, for to associate with a person or group of high prestige is to take on some of their prestige, a notion central to Tajfel's (1970) social identity theory. Prestige is real even if socially constructed in that clusters of nuanced customary behaviours (Packard, 1959 is still a good source) often are nonsensical aside from their prestige implications. Veblen (1899) wrote the defining text on that. These real implications often are delightfully non-obvious. See for example Gladwell's (2005) analysis of the real meaning of an Ivy League education in the United States. Prestige is ironic in the way that it flourishes so abundantly in the seemingly most level of settings: in street gangs (Whyte, 1943), within the highest income echelons of pre-war New England towns (Warner and Lunt, 1942), and among academics, a group comprising the narrowest of micro social classes. By industrial standards, all professors are paid essentially the same, few earning much more than double the base starting salary. Prestige, not money, is the major life force for many academics (Havighurst, 1985:105), but the former is much trickier to measure than the latter.

In Canada, the site for the present study on measuring academic prestige, the prestige system for universities seems comparatively level (Eichler, 1992:83; McLaughlin, 2005, 2006) compared with European countries such as Germany, France or England with their medieval universities, or even the United States with numero uno Harvard founded in 1636. And yet, even in this ex-colonial new-world society, prestige distinctions are never far from the surface. Canadian undergraduates when polled can make some of the obvious prestige distinctions between universities in their country (The Globe and Mail, 2 November, 2005). Sociologists are just as prestige-aware as anyone else, when comparing each other's departments, even though we are the ones who in some contexts will be first to condescendingly label prestige as socially constructed.

It has been many years since a study of the prestige of Canadian sociology departments, but in the 1970 s Brinkerhoff et al. (1974) addressed sociological prestige through a survey of faculty members. The University of Toronto, the oldest of Canada's large universities and one which in its early days deliberately drew prestige via Oxford-educated appointments (Symonds, 1986:242), led the prestige ladder of Canadian sociology departments. Carleton, York and Alberta followed next. Carleton at that time enjoyed the reflected prestige of John Porter, an international "name-brand" sociologist due to his award-winning study The Vertical Mosaic. York, like Carleton, was a newer university with a sociology department receiving good support from its administration. The University of Alberta, comparatively ancient with its 1908 founding, by the 1970s was floating atop the Alberta oil-economy.

I wanted to replicate the Brinkerhoff $e$ al. research for the mid-2000s because I was chair of my department at the time and administrators, suffering from "la fievre de l'evaluation" common today (Gingras, 2008:42), wanted to know where my unit 
ranked before giving us more resources. A survey approach clearly was hard to make credible within the modern survey research climate. Brinkerhoff et al. (1974) had a $54 \%$ response in their reputational survey of Anglo-Canadian sociologists, just clearing the symbolically important 50\% barrier (Babbie, 1973:165). That would be hard to achieve today. Academics have become difficult, cranky hombres to survey. Even after a full-TDM treatment with extended follow-up, it would be difficult to get more than around $35 \%$ response with this population (e.g., Nakhaie and Adam, 2008). High nonresponse would immediately be seen to invalidate a reputational prestige survey of Canadian sociology departments. I thus approached academic prestige behaviourally and arrived at two approaches described below, one to be termed broad but fuzzy the other narrow but clear. Together, they supply an inexpensive and practical, but revealing tool for responding to university administrators who insist on rank orders.

\section{BEHAVIOURAL APPROACHES TO PRESTIGE}

\section{Broad but fuzzy Prestige}

Hiring by university academic units is a behaviour founded, it has been argued, in large part on prestige judgements about the institution granting a job applicant's PhD. It is not to claim that these prestige judgements are upheld within a universal consensus, nor that institutional prestige is the only factor in hiring decisions. Individual merit is not completely irrelevant, and prestige judgements no doubt are not fully consensual but, rather, skewed by social network considerations whereby those faculty members holding $\mathrm{PhD}$ 's from the same university attribute premium prestige to their shared institutional tie (part of the Caplow and McGee, 1958:105, "aggrandizement effect"). In the earlier days when graduate education within many Canadian departments of sociology was new and precarious, the risk of academic colonization via cosy hiring pipelines from the United States or Great Britain was a real fear (Smith, 1992: 126; Cormier, 2002:19). A generation later, Canadian graduate departments were better established and hiring procedures more closely scrutinized. The role of prestige in hiring, however, has not gone away, at least at the author's own university.

Every academic department bears a fingerprint derived from the doctoral origins of its staff. The profiles can be compared and inferences drawn about bases for similarly. Since every department can be thus indexed, the approach is broad, inclusive of all departments large or small, research or teaching focused. The logic being used is the same as in the Stewart et al. (1980) "Cambridge scale" of occupational prestige in Britain, updated more than once since the 1980s (Prandy, 1990; Prandy and Lambert, 2003). In the Cambridge research, survey respondents were asked about the occupations of their friends, a similarity matrix was constructed, and multidimensional scaling analysis used to detect organizing principles suggestive of hierarchy within the matrix. The analysis was able to detect 
the pattern for people having friends in high prestige occupations to themselves hold a high prestige occupation.

Applied to rating sociology departments in Canada, a table was constructed crosstabulating the incumbents (as of 2006) of each of 45 departments of sociology by the institutions from which staff earned their highest degree. Only core full-time, not affiliated or sessional, faculty were included. Most departments make a clear distinction between the two in their faculty listings. Francophone departments were excluded since their facuity recruitment takes place largely within a non-Englishspeaking, often European environment. This left 24 English-Canadian or bilingual departments running graduate programs. ${ }^{2}$ The other 21 departments are predominately undergraduate-instruction English-Canadian departments of sociology and are grouped separately.

Along with Canadian degrees, just over 60 US institutions were represented, 21 from the UK, 2 Australian, several European and a handful from other parts of the world. Across 782 professors employed in the 45 English Canadian universities (and having excluded 10 university calendar entries in which degree information was incomplete), $65 \%$ had Canadian highest degrees. ${ }^{3}$ Twenty-three percent of the 782 faculty members in Canadian anglophone sociology departments held US degrees, $9 \%$ had British degrees, with 3\% French, Australian, or other. I collapsed the US degrees into top 15 versus other in the US National Research Council reputational rankings of graduate programs in sociology. British degrees were recoded into LSE, Oxford, Cambridge, Edinburgh versus other, and the tiny group of non-Canadian, US or British were placed into one group. This gave 45 destination departments by 34 origin departments or clusters of departments. The frequency distribution for each of the 45 was computed, and Euclidian distance scores computed for each pair of departments. Multidimensional scaling analysis (PROXSCAL, in SPSS) was used to produce a two-dimensional solution. As Stewart et al. (1980) showed in their research on occupations, scores from multidimensional scaling may suggest hierarchies, but it is hierarchy as interpreted by the analyst, given meaning according to which observations cluster together.

For the sociology data, the first dimension seems to capture the incidence of top-15 US degrees. In Table 1, the departments have been sorted in descending order on dimension one. The established graduate departments (left-hand column) are separated out from predominately undergraduate (right-hand column). It is no surprise to see the preference of the University of Toronto department for hirings from elite US departments of sociology. The scale value of 1.787 is far above that of York, at 1.174. After Alberta, another department which frequently recruits faculty from the US top-15, the ratings behind the rankings become more bunched.

\footnotetext{
2 Twenty were listed in the American Sociological Association Guide to Graduate Departments, 2006 edition, plus four obvious omissions from the 2006 Guide - - the Ontario Institute for Studies in Education or OISE (for many years a stand-alone institution although now merged with the University of Toronto), University of New Brunswick (Fredericton), University of Calgary and Memorial University. These were included in the present analysis, using website faculty listings. ${ }^{3}$ There are a few MA's and ABD's within the data, which I left in, so the tally strictly speaking is department of highest degree, although most are doctorates.
} 
The top end of dimension one captures several of the same departments as the Brinkerhoff reputational survey. Dimension two identifies departments of sociology with a strong loading of University of Toronto degrees among its faculty. On this second dimension, also shown in Table 1, the rank order begins; York, Guelph, Windsor. From the undergraduate column King's University College (London, Ontario) and Brock have high scores on dimension two.

Table 1: Multidimensional Scaling Analysis of Origins of Highest Degrees of Faculty Members From 45 English Canada Departments of Sociology

\begin{tabular}{|c|c|c|c|c|c|c|c|}
\hline \multirow[b]{3}{*}{ Toronto (47.8) } & \multicolumn{3}{|c|}{$\begin{array}{l}\text { Established Graduate } \\
\text { Departments }\end{array}$} & & \multicolumn{3}{|c|}{$\begin{array}{l}\text { Predominately } \\
\text { Undergraduate }\end{array}$} \\
\hline & \multicolumn{2}{|c|}{$\begin{array}{l}\text { N of D1 } \\
\text { Faculty\# }\end{array}$} & \multicolumn{2}{|l|}{ D2 } & \multicolumn{2}{|c|}{$\begin{array}{l}\mathrm{N} \text { of } \mathrm{D} 1 \\
\text { Faculty\# }\end{array}$} & \multirow[t]{2}{*}{ D2 } \\
\hline & 49 & 1.787 & -1.208 & & & & \\
\hline York $(6.9)$ & 44 & 1.174 & 1.101 & & & & \\
\hline Alberta (22.0) & 31 & .818 & .374 & & & & \\
\hline Windsor (5.1) & 33 & .655 &.$m$ & King's U. Coll (ON) & 23 & .168 & .524 \\
\hline McGill (24.6) & 19 & .631 & .854 & Regina & 15 & .064 & .329 \\
\hline Carleton (3.4) & 28 & .581 & -.051 & Winnipeg & 15 & .051 & -619 \\
\hline Westem (24.9) & 27 & .576 & .290 & St Thomas (NB) & 10 & -.082 & .374 \\
\hline $\operatorname{OISE}(2.7)$ & 16 & .558 & .247 & Mt. St. Vincent & 10 & .112 & .130 \\
\hline Dalhousie (3.5) & 19 & .515 & .059 & Brock & 17 & -.138 & .528 \\
\hline Manitoba (7.7) & 22 & .452 & .148 & UPEI & 8 & -.168 & .095 \\
\hline Calgary (19.4) & 23 & .382 & -.418 & Brandon & 5 & .228 & -.400 \\
\hline Queen's (21.0) & 19 & .250 & -019 & Cape Breton & 10 & .248 & -.192 \\
\hline Guelph (9.6) & 24 & .168 & .825 & Nipissing & 10 & -287 & -.345 \\
\hline Memorial (2.3) & 19 & .154 & .136 & Acadia & 17 & -.298 &. .573 \\
\hline Simon Fraser (1.3) & 13 & .089 & .119 & WLU & 17 & -.355 & .410 \\
\hline Waterloo (15.2) & 13 & .061 & .154 & St. Mary's & 16 & -.385 & .144 \\
\hline McMaster (16.2) & 16 & .003 & -.215 & Lethbridge & 11 & -399 & -.326 \\
\hline Victoria (42.1) & 17 & .002 &. .466 & Mount Allison & 3 & -.453 & -.106 \\
\hline UBC (28.1) & 11 & -.131 & .018 & Athabasca & 5 & -.405 & -.259 \\
\hline Saskatchewan (2.8) & 20 & -.222 & .348 & UNB- St. John & 8 & -.474 & .000 \\
\hline Lakehead (2.8) & 10 & -.271 & 019 & St. Francis Xavier & 13 & -.491 & .192 \\
\hline UNB-Fredericton (2.2) & 14 & -.357 & .053 & Bishop's & 7 & -.544 & -.013 \\
\hline Laurentian (5.7) & 14 & $\cdot .386$ & .203 & Trent & 13 & -.579 & .252 \\
\hline Concordia (2.7) & 34 & -1.181 & .109 & Ottawa & 24 & -891 & -.561 \\
\hline
\end{tabular}

\# From 2006 ASA Guide to Graduate Departments, or from summer 2006 web information for those not listed in the guide. For some departments, it was apparent that rapid expansion had taken place between early summer and the date of final checking of figures in October 2006. Since web sites change so quickly, and old versions of calendars not always retrievable, an exact check was not always possible. Ryerson was excluded since degree information was very sparse in the web listings. Moncton and Sainte Anne excluded since both are francophone.

D1=Dimension one from multidimensional scaling (interpreted as extent of recruitment of faculty from elite US departments), D2=dimension two (interpreted as extent of penetration by University of Toronto graduates).

() = citations per faculty member in social sciences citation index, 1995-2005. 
With the multidimensional scaling, we are of course not measuring prestige directly, but rather are trying to tap into possible "status leakage" (Podolony, 2005:15). A Canadian department which loads up on graduates of elite US schools is sharing in the prestige from the top of the US ranking system. And the eliteschool graduates taking Canadian jobs are acknowledging that their posting is an appropriate outlet for their high-prestige credentials. With the second dimension, the status leakage implication is that the way to build a highly respectable department of sociology in the hinteriand is to leach off prestige from the University of Toronto by hiring many of its graduates. The approach just shown is fuzzy in that the dimensions take their name and meaning from the eyes of the observer. The next approach is clearer to interpret, but necessarily narrower.

\section{Narrow but Clear Prestige}

By restricting the data to a smaller subset, a more powerful inference about prestige can be drawn from the data on hiring behaviour. The theme of prestige being embedded in the exchange aspect of academic hiring traces back at least as far as the Caplow and McGee (1958) classic and as recently as Burris (2004), but may first have been given full conceptual formulation by an anthropologist, in Hurlbert's (1976) examination of rankings of US departments of anthropology. Invoking social exchange theory, she noted the similarity of academic hirings to marriage in tribal societies. "(H)igher status is conferred upon the giver if the receiver cannot reciprocate in kind," Hurlbert (1976:273) wrote. If a tribe sends a bride to marry into another tribe, but won't reciprocate by accepting a bride, a prestige statement has been made. ${ }^{4}$ This theme was applied implicitly to sociology departments in the United States by Oromaner (1970: Table 4). A membrane-like pattern occurs, whereby graduates from high prestige units gain jobs at all levels, high and low, but graduates from lower prestige departments find entry into the job market among the top ten or fifteen schools impenetrable, and must take positions at places approximating or lower than the prestige level of their own PhD-granting department. Hargens and Farr (1973) used the term "institutional inbreeding" to describe the membrane effect in hiring patterns among natural scientists in the US. The prestige-claim behind asymmetric exchanges is a generic social process, codified as long ago as Blau's (1963) classic study of bureaucracy and as recently as Podolny's (2005) work on deal-making among banks. Along with hiring, the present focus, the asymmetric exchanges factor into such features of academic life as citation patterns (Nock, 1993:chapter 5).

\footnotetext{
"I am using "status" as the more general term for a department's position ("the positive or negative honor, prestige, power etc. attaching to a position or an individual within a system of social stratification" (Jary and Jary, 1991:494]), and prestige specifically to denote the ideas in people's heads about "reputation or influence arising from success" (Webster definition), or, from the OED, "blinding or dazzling influence." In the OED definition, prestige includes a connotation of "illusion," "a conjuring trick." This last component links nicely with the sociological theme of prestige having a socially constructed component.
} 
The mapping of who hires PhD's from whose department gives a far sparser matrix than seen within the much larger US university system. Hurlbert (1976), for example, could compare $80 \mathrm{PhD}$-granting departments of anthropology in the US, and the number for American sociology was 94 in the Burris (2004) analysis. In Canada, the exchange network narrows down to just 17 Canadian departments of sociology - those in English Canada, with doctoral programs, who had at least one of their PhD's placed in a full-time position in a Canadian sociology $\mathrm{PhD}$-granting university, as of $2006 .{ }^{5}$ Following Podolny (2005), I used a measure of "power and centrality" in exchange networks from Bonacich (1987). The raw input data is the same cross-tabulation of department of destination by department of doctoral origin already described, but now including only those faculty members from departments involved in $\mathrm{PhD}$ "exchanges." Bonacich's (1987) score is subtle because it is sensitive to both direct and indirect exchanges between departments. An example of an indirect exchange would be Toronto and McMaster. Toronto has no McMaster graduates, but Alberta has two according to the 2006 Guide to Graduate Departments published by the American Sociological Association. Since Toronto has four Alberta graduates on its faculty, McMaster gains points (albeit weighted down from the score for a direct exchange) for the indirect tie to a department that on the whole sends more doctorates into the Canadian system than it absorbs. As a song from the 1930s said: "I danced with a man, who danced with a girl, who danced with the Prince of Wales." Footnote 6 gives fuller details on the Bonacich measure.

The prestige order derived from the hiring matrix is laid out in Table 2. The distribution places Toronto in a clearly dominant top position. Third place York and $4^{\text {th }}$ place Alberta have appeared in discussion above. McMaster is a clear gainer in prestige since the 1970s ratings by Brinkerhoff et al., moving from $7^{\text {th }}$ place in 1973 to $2^{\text {nd }}$ in the 2006. Prestige accrues partly from large departments which have been turning out PhD's for many years, but these doctorates have to be placed among the other PhD-granting departments to do well in the ratings. It is easy to weight the data to imagine that every department had produced as many graduates as, say, Toronto's 68 within the set of institutions being examined, but such an adjustment has surprisingly little effect on scores. A high score is gained by a department having as many as possible graduates dispersed as widely as possible throughout the system, and simply weighting number of graduates does not create that. In the data shown, self-hires (a department hiring its own graduates) have been left in the data since this has little effect on the scores. ${ }^{6}$

\footnotetext{
"This excluded Memorial and Windsor. Victoria listed "PhD by special arrangement" within the 2006 ASA Guide and was not included within the hiring matrix.

${ }^{6}$ The Bonacich measure computes, for each pair of departments, the number of own hired as a percentage of the total number in the exchange. Then it computes the number of other hired over the same base. Toronto, for example, has three York PhD's and York has 12 from Toronto, for a denominator of 15 . The figure 0.8 goes into the Toronto score, with the other 0.2 going to York. The Bonacich measure sums these calculations for all pairs, then rakes the data for indirect linkages. See Podolny (2005: chapter 3) for more explanation. Self-hires were scored as 0.5 , indicating neither advantage nor disadvantage. Self-hires can indicate, alternatively, self-confidence (to get the best, hire your own) or desperation (no one will work in our department, so we'll have to hire one of our own)! Eleven of the 17 departments had one or more self-hires. $\beta$, the weighting coefficient for indirect linkages, was set to 0.1 in computing the Bonacich scores.
} 
Table 2: Who Hires Whose Scores Within Network of 17 PhD-Exchanging Canadian Anglophone Sociology Departments

\begin{tabular}{|c|c|c|}
\hline $\begin{array}{l}\text { Bonacich measure } \\
\text { (Prestige score) } \\
\text { intervals }\end{array}$ & $\begin{array}{l}\text { Number of } \\
\text { sociology } \\
\text { departments }\end{array}$ & $\begin{array}{l}\text { Individual } \\
\text { scores }\end{array}$ \\
\hline
\end{tabular}

23 to 25

1

Toronto (23.05)

21 to $<23$

18 to $<21$

15 to $<18$

12 to $<15$

McMaster (13.01) York (12.77) Alberta (12.20)

9 to $<12$

6 to $<9$

3 to $<6$

0 to $<3$
Carleton (8.50) British Columbia (8.33)

McGill (5.95) Simon Fraser (5.02) Calgary (4.58)

Western (2.80) OISE (2.66) Waterloo (2.02) Queen's (1.88) UNB-Fredericton (1.05) Manitoba (0.53) Saskatchewan (0.53) Dalhousie (0.00)

\section{VALIDATION AND VALIDITY ISSUES}

It is a feature of Anglo-Canadian sociology departments, perhaps unusual compared with other countries (although see Sturgis and Clemente, 1973:176), that academic prestige and academic productivity at the departmental level are pretty loosely coupled. This was established by Westhues (1974) who reacted to the Brinkerhoff et al. (1974) reputational survey by compiling citation index scores for faculty members in each of the major sociology departments. The results were quite startling: Toronto dropped to $4^{\text {th }}$ place, superceded by McGill first in citations per staff member, followed by Simon Fraser University, one of the new universities from the $1960 \mathrm{~s}$, and the University of Western Ontario, one of the long-established Ontario institutions. The simple correlation between prestige and research productivity in the early 1970 s comparison was just $r=.41$ for 18 departments coded in each of the 1970s studies, and an even lower $r=.26$ using just the 14 
departments common to my hiring exchange matrix of 17 departments (the 14 are those listed in Table 2, but deleting Memorial, Victoria, and Windsor).

I re-generated citation index scores for the $2000 \mathrm{~s}$, coding from 1995 to the end of 2005. Scores for the 24 graduate intensive departments appear in brackets after names of universities in Table 1. The 21 more undergraduate focused departments were not coded for citations since comparison would be unfair in view of the heavier teaching loads in such units. For the subset of 14 departments of sociology considered both in the $1970 \mathrm{~s}$ and the 2000 s data, the more recent correlation between prestige and research productivity was $r=.39$. For computing these correlations, the scores have been forced into rank order (which creates equal variances in all variables), to simplify comparison across the years. Granted the construct validation standard inherited from the 1970 s is generous, but the $2000 \mathrm{~s}$ data clearly are meeting and in fact exceeding it. The 2006 inferred prestige scores "look like" prestige scores in their stickiness too: the two prestige measures (i.e., survey ratings from circa 1973; hiring matrix from 2006) are related at $r=.81$ while the citation scores for the two years correlate at only .30. There is much more departmental mobility on the productivity side than on the prestige side.

The fit between the different indicators for the 2000s data is sketched in Table 3, again using simple correlations. The data base here is the tiny $\mathrm{n}$ of 17 departments. We are, however, looking here at a population rather than a sample (the population of sociology departments in Canada which have exchanged PhD's). Computing significance tests would therefore be senseless. Also, the units of observation are summations from a data base of over 700 faculty members so the 17 data points are far more stable than observations for individuals would be.

Table 3: Prestige and Citation Index Impact - Pearsonian Correlations

\begin{tabular}{llll}
\hline & $\mathrm{X}_{2}$ & $\mathrm{X}_{3}$ & $\mathrm{X}_{4}$ \\
$\mathrm{X}_{1}$ Bonacich measure & .68 & $.26^{*}$ & .60 \\
$\mathrm{X}_{2}$ Elite foreign-trained faculty & 1.00 & $.26^{*}$ & .50 \\
$\mathrm{X}_{3}$ Toronto-trained faculty & & 1.00 & $-.41^{*}$ \\
$\mathrm{X}_{4}$ Citation index score & & & 1.00 \\
\hline
\end{tabular}

17 departments

Note: the correlation between $\mathrm{X} 2$ and $\mathrm{X} 3$ is zero by definition over the full 45 departments.

- With Toronto removed $(n=16)$.

Part of Table 3 shows the relationship between the narrow but clear prestige from the Bonacich measure and the broad but fuzzy prestige from the multidimensional scaling. The Bonacich scores have some noticeable coincidence ( $r$ of nearly .7 ) with MDS dimension D1 of foreign-trained faculty from elite schools, but much less 
with the "Toronto" dimension (D2 from Table 1). Validating the prestige measures against citation counts for research productivity, the fit is highest for the Bonacich measure $(r=60)$, followed by the foreign-training score $(r=.50)$ and a seemingly anomalous $\mathrm{r}=$ negative .41 for concentration of faculty trained in Toronto. That does not mean that sociologists trained at the University of Toronto are unproductive, just that Toronto $\mathrm{PhD}$ 's are broadly distributed among both more and less productive Canadian sociology departments, with greatest penetration among the less productive. The correlation of .60 just noted is larger than the $r=.39$ from above because raw scores, the ratings rather than rankings, are now being used. As seen from the detailed data at the foot of Table 2, the bottom end of the prestige distribution is very clustered and the rank order stretches that. The forced stretching of a condensed distribution is a common problem (see Sturgis and Clemente, 1973:176) with rank order approaches to assessment which bedevils the influential MacLean's magazine rankings of Canadian universities.

The validation conclusion from the above is clearly that the Bonacich measure holds the highest construct validity while the first dimension from multidimensional scaling of faculty origins adds further information having prestige implications. The second dimension in this analysis is rather quirky and susceptible to ecological fallacy in interpretation unless handled with care. It probably has little connection with academic prestige.

\section{INTERPRETATION AND CONCLUSION}

Prestige is real in Thomas's sense, but that does not necessarily make prestige accurate or just. In the small communities and invisible colleges which academics form into, it is inadequate to invoke the industrial society notion of prestige hierarchy as a spontaneously emerged social structure by which excellence is recognized (e.g., Treiman, 1977, with reference to occupational prestige). Today, even society-wide occupational prestige is better realized to be susceptible to social construction (e.g., Zhou, 2005), and this perspective seems especially well applied in the academic hiring minuet. Someone joining a prestigious department gains a "derivative reputation," but as noted these prestige transfers or leaks are reciprocal too (Caplow and McGee, 1958:107-108). A department acquiring a star is making prestige for itself. The possibilities for intended social construction of academic prestige have become fully appreciated by Canadian universities, with imagecreation now a well-entrenched practice, reflected in advertisements in newspapers. The Federal Government's Canada Research Chair program, by promoting institutional mobility among faculty stars, has served the prestige-constructing aspirations of Canadian universities. The weak fit found when prestige is validated against research production illustrates how greatly the prestige dimension has its own life.

One complexity in measuring prestige among Canadian sociology departments might apply in European countries and the smaller-population English-speaking 
countries as well. There are two career styles for a Canadian anglophone sociologist: one is to seek visibility on the world stage by placing articles in leading US journals. It is this strategy which builds up a high count in the citation index. The other is to publish within the country, arguing that it is legitimate for social science to be nationally specific. This career dilemma has been known for a long time and never forgotten (e.g., Ambert, 1980; Baer, 2005: footnote 16). The same issue seemed present in Chall's (1988) finding that non-US sociologists assigned far higher rank to Sociology and Sociological Review (both UK) than did their US counterparts. ${ }^{7}$ Elsewhere, the analogue might be whether to publish in one's native non-English tongue or write for the English-language dominated international audience. As part of the present study I coded research in terms of articles in the two general-topic sociology journals in Canada (Canadian Review of Sociology and Anthropology and Canadian Journal of Sociology). Authorship of books reviewed in those two outlets was also part of this tally because the citation index is inattentive to book authorship (Berkowitz, 2005). The fit between these two supplementary productivity measures and citation scores was as weak as that between citations and prestige. Judged by reactions from colleagues, these altemative measures of research productivity create as many problems as they solve and so I do not feature them here. Thirty years ago, the two general-topic journals might have picked up much of the anglo-sociological research in Canada, but since then many more subject matter specific journals have appeared.

Another obstacle to indexing academic prestige is the rise of affiliated faculty of various types. What is "the department of sociology" in a university today? Does it include emeritus professors still listed on the masthead, with involvement ranging from indispensable to negligible? How do various person-sharing arrangements described with terms such as joint, cross, and adjunct appointments fit in? My resolution was to rely on how departments described themselves when designating their "full-time" faculty in the ASA Guide to Graduate Departments. In this study the unit of analysis is truly the department rather than the individual and results are robust in the face of decisions to include or exclude a few individuals.

\section{REFERENCES}

Ambert, Anne-Marie (1980) Is publishing in Canada worth it? Society-Société 4 (1):4-5.

Babbie, Earl R. (1973). Survey Research Methods. Beimont, Calif.: Wadsworth.

Baer, Doug (2005) On the crisis in Canadian Sociology: comment on McLaughlin. Canadian Journal of Sociology 30:491-502.

\footnotetext{
7 Judging from the low rating for the Canadian Review of Sociology and Anthropology in Chall's scores by non-North Americans, Canada was not seen as part of a rest-of-the-world sociology but rather was a backwater within the continent it shares with the US.
} 
Berkowitz, Peggy (2005). Bibliometric indicators- use with caution. University Affairs, March issue: 29.

Blau, Peter M. (1963). The Dynamics of Bureaucracy. Second Edition. Chicago: University of Chicago Press.

Bonacich, Phillip (1987) Power and centrality: a family of measures. American Journal of Sociology 92: 1170-1182.

Brinkerhoff, Merlin B., Joseph E. DiSanto and James S. Frideres (1974). Canadian sociologists view their discipline. CSAA Bulletin 32 (February):8-9.

Burris, Val (2004). The academic caste system: prestige hierarchies in $\mathrm{PhD}$ exchange networks. American Sociological Review 69:239-64.

Caplow, Theodore and Reece Jerome McGee (1958). The Academic Marketplace. New York. Basic Books.

Chall, Leo P. (1988). Evaluation of sociology serials by a select sample of sociologists. Bulletin de Méthodologie Sociologique N. 17: 70-83.

Cormier, Jeffrey J. (2002). Nationalism, activism, and the Canadian Sociology and Anthropology community, 1967-1985. American Sociologist 33:12-26.

Eichler, Margrit (1992). The unfinished transformation: women and feminist approaches in Sociology and Anthropology. Pp. 71-101 in Fragile Truths: TwentyFive Years of Sociology and Anthropology in Canada, edited by William K. Carroll, Linda Christiansen-Ruffman, Raymond F. Currie, and Deborah Harrison. Ottawa: Carleton University Press.

Gingras, Y. (2008). La fievre de l'evaluation de la recherche - du mauvais usage de faux indicateurs. Bulletin de Méthodologie Sociologique N. 100: 42-44.

Gladwell, Malcolm (2005). Getting in. The New Yorker, October $10^{\text {th }}$.

Hargens, Lowell L. and Grant M. Farr (1973) An examination of recent hypotheses about institutional inbreeding. American Journal of Sociology 78:1381-1402.

Havighurst, Robert J. (1985) Aging and productivity: the case of older faculty. Pp 98-111 in Faculty Vitality and Institutional Productivity: Critical Perspectives for Higher Education, edited by Shirley M. Clark and Darrell R. Lewis. New York: Teacher's College Press, Columbia University.

Hurlbert, Beverly McElligott (1976). Status and exchange in the profession of Anthropology. American Anthropologist 78:272-284. 
Jary, David and Julia Jary (1991). The HarperCollins Dictionary of Sociology. New York: HarperCollins.

Merton, Robert K. (1968). The Matthew Effect in science. Science 159:56-63.

McLaughlin, Neil (2005). Canada's impossible science: historical and institutional origins of the coming crisis in Anglo-Canadian sociology. Canadian Journal of Sociology 30:1-40.

McLaughlin, Neil (2006). Wither the future of Canadian sociology? Thoughts on moving forward. Canadian Journal of Sociology 31:107-130.

Nakhaie, Reza and Barry Adam (2008). Political affiliation of Canadian university professors. Presented at the $43^{\text {rd }}$ Annual Meeting of the Canadian Sociological Association, Vancouver, BC, 3 June.

Nock, David A. (1993). Star Wars in Canadian Sociology: Exploring the Social Construction of Knowledge. Halifax: Fernwood.

Oromaner, Mark Jay (1970). A note on analytical properties and prestige of sociology departments. American Sociologist 5:240-244.

Packard, Vance O. (1959). The Status Seekers: An Exploration of Class Behavior in America and the Hidden Barriers that Affect You, Your Community, Your Future. New York: McKay.

Podolny, Joel M. (2005). Status Signals: A Sociological Study of Market Competition. Princeton: Princeton University Press.

Prandy, K. (1990). The revised Cambridge scale of occupations. Sociology 24:62955.

Prandy, K. and Lambert, P. (2003). Marriage, social distance and the social space: an alternative derivation and validation of the Cambridge scale. Sociology 37:397411.

Smith, Dorothy E. (1992) Remaking a life, remaking sociology: reflections of a feminist. Pp.125-134 in Fragile Truths: Twenty-Five Years of Sociology and Anthropology in Canada. Ottawa: Carleton University Press. Edited by William K. Carroll, Linda Christiansen-Ruffman, Raymond F. Currie, and Deborah Harrison. Ottawa: Carleton University Press.

Stewart, A., Prandy, K. and Blackburn, R.M. (1980). Social Stratification and Occupations. London: Macmillan.

Sturgis, Richard B., and Frank Clemente (1973). The productivity of graduates of 50 sociology departments. American Sociologist 4:169-180. 
Symonds, Richard (1986). 'Oxford and Empire: The Last Lost Cause? London: MacMillan.

Tajfel, Henri (1970). Experiments in intergroup discrimination. Scientific American 223:96-102.

Treiman, Donald J. (1977) Occupational Prestige in Comparative Perspective. New York: Academic.

Veblen, Thorstein (1899) The Theory of the Leisure Class. New York: The Macmillan Company.

Warner, W. Lloyd and Paul S. Lunt (1942) The Status System of a Modern Community. New Haven: Yale University Press.

Westhues, Kenneth (1974) On ranking graduate departments of sociology in Canada. CSAA Bulletin 33 (April):11-12.

Whyte, William F. (1943). Street Corner Society: The Social Structure of an Italian Slum. Chicago: University of Chicago Press.

Zhou, Xueguang (2005) The institutional logic of occupational prestige rankings: reconceptualization and reanalyses. American Journal of Sociology 111:90-140. 
Copyright of BMS: Bulletin de Methodologie Sociologique is the property of I'Association Internationale de Methodologie Sociologique (AIMS) and its content may not be copied or emailed to multiple sites or posted to a listserv without the copyright holder's express written permission. However, users may print, download, or email articles for individual use. 